Hal : $23-28$

\title{
PENINGKATAN KEMAMPUAN PEMECAHAN MASALAH MATEMATIS MELALUI PEMBELAJARAN BERBASIS MASALAHPADASISWA KELAS X SMK AR-RAHMAN MEDAN
}

\section{IMPROVEMENT OF MATHEMATICAL PROBLEM SOLVING ABILITY THROUGH PROBLEM-BASED LEARNING PROBLEM CLASS X STUDENTS OF AR-RAHMAN MEDAN VOCATIONAL SCHOOL}

\author{
Nilam Sari ${ }^{1}$, Vera Dewi K Ompusunggu ${ }^{2}$, Muhammad Daliani ${ }^{3}$ \\ ${ }^{123}$ Program Studi Pendidikan Matematika,Universitas Quality, \\ Jl. Ngumban Surbakti No.18, Sempakata, Kec. Medan Selayang, Kota Medan, email: nilamsarie@gmail.com \\ ${ }^{4}$ Program Studi Pendidikan Matematika, STKIP Labuhan Batu \\ Jalan Sisingamangaraja No. 126A, KM, 3,5 Aek Tapa Rantauprapat
}

\begin{abstract}
Abstrak
Penelitian ini bertujuan untuk mengetahui: Apakah peningkatan kemampuan pemecahan masalah matematis siswa yang memperoleh pembelajaran berbasis masalah lebih baik daripada siswa yang memperoleh pembelajaran konvensional. Penelitian ini merupakan penelitian semi eksperimen dengan populasi penelitian adalah seluruh siswaseluruh siswa kelas X SMK AR-Rahman Medan.Pemilihan sampel dilakukan secara acak dan terpilih 2 kelas. Instrumen yang digunakan yakni tes kemampuan pemecahan masalah dengan materi sistem persamaan linear.Data dalam penelitian ini dianalisis dengan menggunakan analisis parametrik. Analisis statistik data dilakukan dengan analisis uji $t$. Hasil penelitian menunjukkan bahwa: (1)Peningkatan kemampuan pemecahan masalah matematik siswa yang memperoleh pembelajaran berbasis masalahlebih tinggi daripada siswa yang memperoleh pembelajaran konvensional; (2) Terdapat perbedaan yang signifikan antara peningkatan kemampuan pemecahan masalah matematika siswa yang memperoleh pembelajaran berbasis masalah dengan siswa yang memperoleh pembelajaran konvensional; (3) Diantara ke empat aspek pemecahan masalah, rata-rata peningkatan yang paling tinggi pada aspek "membuat model matematis" sebesar 0,635 dengan kriteria sedang.Berdasarkan hasil penelitian ini,peneliti menyarankan agar pembelajaran berbasis masalah pada siswa dapat dijadikan alternatif bagi guru untuk meningkatkan kemampuan pemecahan masalah siswa khususnya pada materi Sistem Persamaan Linear.
\end{abstract}

Kata Kunci: Kemampuan Pemecahan Masalah, PBM

\begin{abstract}
This study aims to determine: Is increasing the ability of mathematical problem solving students who get problem based learning better than students who get conventional learning. This research is a semiexperimental study with the study population as all students of all grade $X$ students of SMK AR-Rahman Medan. The sample selection is done randomly and 2 classes are chosen. The instrument used is a test of problem solving skills with the material system of linear equations. Data in this study were analyzed using parametric analysis. Statistical analysis of data was performed by t test analysis. The results showed that: (1) Increased mathematical problem solving abilities of students who obtained problem-based learning were higher than students who obtained conventional learning; (2) There is a significant difference between improving students' mathematical problem solving abilities that obtain problem-based learning and students who obtain conventional learning; (3) Among the four aspects of problem solving, the highest average increase in the aspect of "making a mathematical model" of 0.635 with moderate criteria. Based on the results of this study, researchers suggest that problem-based learning in students can be used as an alternative for teachers to improve students' problem solving abilities, especially in the Linear Equation System material.
\end{abstract}

Key Words: Problem Solving Ability, PBL

\section{Pendahuluan}

Matematika merupakan suatu pelajaran yang dapat memberi sumbangan untuk mengatasi rendahnya kualitas sumber daya manusia Indonesia.Karena dengan bermatematika individu diharapkan mampu menyelesaikan masalah-masalah yang kompleks, selain itu dapat menjadi individu yang mandiri, kreatif dan juga dapat menjadi individu yang kompeten.Ansari menjelaskan bahwa "pembelajaran matematika bertujuan untuk mengembangkan keterampilan dan memandirikan individu dalam belajar berkolaborasi, melakukan penilaian diri (refleksi) serta mendorong individu membangun pengetahuannya sendiri”.[1]. 
Kemampuan pemecahan masalah perlu diterapkan dalam pembelajaran guna meningkatkan hasil belajar matematika pada siswa.Pemecahan masalah merupakan suatu upaya yang dilakukan untuk menyelesaikan permasalahan yang ditemukan. Polya mengatakan pemecahan masalah adalah salah satu aspek berpikir tingkat tinggi, sebagai proses menerima masalah dan berusaha menyelesaikan masalah tersebut [4].Selain itu, pemecahan masalah merupakan suatu aktivitas intelektual untuk mencari penyelesaian masalah yang dihadapi dengan menggunakan bekal pengetahuan yang sudah dimiliki.Siswa yang terbiasa memecahkan masalah akan meningkatkan potensi intelektualnya, dan rasa percaya diri akan meningkat serta tidak akan takut ketika dihadapkan pada masalah lainnya. Pada penelitian ini kemampuan pemecahan masalah meliputi 3 proses penyelesaian seperti yang diungkapkan oleh Napitupulumenyatakan ada 3 (tiga) proses dalam menemukan jawaban yakni: 1) membuat model matematis dari suatu situasi yang berhubungan dengan masalah dunia nyata, 2) memilih strategi pemecahan masalah yang tepat dan 3) menjelaskan jawaban yang diperoleh dan memeriksa kebenarannya [3]. Ketiga proses ini yang akan dijadikan acuan untuk melihat peningkatan kemampuan pemecahan masalah matematis siswa.

Arendsmenjelaskan "pembelajaran yang baik adalah guru memberikan berbagai situasi (masalah) sehingga anak dapat bereksperimen, mengujicobakan berbagai hal untuk melihat apa yang akan terjadi, memanipulasi benda-benda, simbol-simbol, melontarkan pertanyaan dan mencari jawabannya sendiri, kemudian membandingkannya dengan temuan teman yang lain"[2], sehingga peserta didik menjadi lebih kreatif dalam berpikir. Jadi setiap pendidik/guru diharapkan dapat menitikberatkan pengajaran matematika pada pengembangan kemampuan pemecahan masalah untuk dapat mencapai suatu pembelajaran yang dikatakan baik dan bermakna.Pembelajaran yang menjadikan masalah sebagai modal utama adalah pembelajaran berbasis masalah.Jadi sesuai dengan tuntutan masa yang berkembang dari waktu ke waktu, diperlukan suatu pembelajaran matematika yang berbasis masalah (problem-based learning) yang disesuaikan dengan tingkat perkembangan kognitif siswa. Menurut Arends "tujuan intruksional dari pembelajaran berbasis masalah adalah membantu peserta didik mengembangkan kemampuan keterampilan investigatif dan keterampilan mengatasi masalah dan memungkinkan peserta didik untuk mendapatkan rasa percaya diri atas kemampuannya sendiri, untuk berpikir dan menjadi pembelajar yang mandiri"[2]. Ada 5 tahapan dalam pembelajaran berbasis masalah diantaranya: (1) Mengorientasikan siswa pada masalah, (2) Mengorganisasikan siswa untuk belajar, (3) Membimbing penyelidikan individu maupun kelompok, (4) Mengembangkan dan menyajikan hasil karya, (5) Menganalisis dan mengevaluasi proses pemecahan masalah [2].

Dengan demikian peneliti ingin menerapkan pembelajaran berbasis masalah pada siswa kelas X SMK Ar-Rahman Medan dengan tujuan untuk meningkatkan kemampuan pemecahan masalah siswa dikarenakan berdasarkan hasil observasi dan data yang ditemukan pada siswa kelas $\mathrm{X}$ tersebut tingkat kemampuan pemecahan masalahnya sangat rendah, untuk lebih jelasnya tujuan dari penelitian ini adalah: Untuk mengetahui apakah peningkatan kemampuan pemecahan masalah matematik siswa yang diajarkan melalui pembelajaran berbasis masalah lebih baik dibandingkan dengan pembelajaran konvensional.

\section{Metode Penelitian}

Populasi yang dimaksud pada penelitian ini adalah seluruh siswa kelas X SMK Ar-Rahman Medan sebanyak 6 kelas,sedangkan sampel penelitian adalah kelas Xa sebagai kelas Eksperimen dan kelas Xb sebagai kelas kontrol. Sedangkan desain yang digunakan dalam penelitian ini adalah desain eksperimen dengan kelompok kontrol pretesdan postes. Ruseffendi menggambarkan desain penelitian seperti ini adalah sebagai berikut:
A: $\mathrm{O} \quad \mathrm{X}_{1} \mathrm{O}$
A: $O \quad O$
Keterangan :
$A=$ Acak (Pemilihan sampel secara acak)
$\mathrm{O}=$ Tes (pretes dan postes)
$\mathrm{X}_{1}=$ Pengajaran yang dilakukan dengan pendekatan pembelajaran berbasis masalah.[5] 
Hal : $23-28$

Pada penelitian ini, instrumen yang digunakan yakni tes kemampuan pemecahan masalah yang terdiri dari 5 butir soal dalam bentuk uraian.

Untuk memperoleh data dari kemampuan pemecahan masalah diawali dengan pemberian pretes pada masing-masing kelas yakni kelas kontrol dan kelas eksperimen.Setelah pembelajaran berbasis masalah dilakukan pada kelas eksperimen dan pembelajaran konvensional pada kelas kontrol, diakhir pembelajaran masing-masing kelas di berikan postes. Untuk melihat peningkatan ( $\mathrm{N}$-gain) dengan rumus.

$$
\mathrm{N} \text { - Gain }=\frac{\text { skor postes }- \text { skor pretes }}{\text { skor maksimum }- \text { skor pretes }}
$$

Selanjutnya sebelum data tersebut diuji signifikansinya agar hasilnya lebih teliti maka data harus melalui tahap uji normalitas dan homogenitas terlebih dahulu. Analisis statistik yang digunakan untuk menguji hipotesis kemampuan pemecahan masalah pada penelitian ini menggunakan uji t. Dari uji statistik yang dilakukan, apabila telah diketahui perbandingan tingkat signifikannya kemudian dapat ditarik kesimpulan akhir penelitian apakah hipotesis bisa di terima atau ditolak. Untuk lebih jelasnya mengenai hipotesis dan analisis datanya, berikut adalah tabel keterkaitan antara permasalahan, hipotesis dan jenis uji statistik yang digunakan :

Tabel 1. Keterkaitan Permasalahan, Hipotesis dan Jenis Uji Statistik yang digunakan

\begin{tabular}{|l|l|c|c|c|c|}
\hline No. & \multicolumn{1}{|c|}{$\begin{array}{c}\text { Permasalahan } \\
\text { Penelitian }\end{array}$} & Hipotesis & $\begin{array}{c}\text { Klp. } \\
\text { Data }\end{array}$ & Alat Uji & Uji Statistik \\
\hline $\begin{array}{l}\text { Perbedaan peningkatan } \\
\text { kemampuan pemecahan } \\
\text { masalah matematis } \\
\text { antara siswa yang } \\
\text { memperoleh } \\
\text { pembelajaran berbasis } \\
\text { masalah dengan siswa } \\
\text { yang memperoleh } \\
\text { pembelajaran } \\
\text { konvensional }\end{array}$ & 1 & $\begin{array}{c}\text { PMA } \\
\text { dan }\end{array}$ & $\begin{array}{c}\text { Tes } \\
\text { PMB } \\
\text { pemecahnan } \\
\text { masalah }\end{array}$ & Uji t \\
\hline
\end{tabular}

Keterangan:

PMA adalah kemampuan pemecahan masalah melalui pembelajaran berbasis masalah.

PMB adalah kemampuan pemecahan masalah melalui pembelajaran konvensional.

\section{Hasil Penelitian dan Pembahasan}

Data kemampuan pemecahan masalah diperoleh dari skor pretes dan postes yang diberikan di awal dan akhir pembelajaran. Setelah data kemampuan pemecahan masalah diolah diperoleh nilai rata-rata N-gain kelas ekperimen sebesar 0,43 dan kelas control sebesar 0,25. Jadi rata-rata $\mathrm{N}$-gain kelas eksperimen lebih tinggi dibandingkan rata-rata $\mathrm{N}$-gain di kelas kontrol dengan selisih rata-rata $\mathrm{N}$-gain antara kelas ekperimen dan kelas kontrol sebesar 0,18 .

Berdasarkan 4 (empat) aspek pemecahan masalah jika ditinjau perolehan perindikator pada kelas eksperimen diperoleh rata-rata peningkatan ( $\mathrm{N}$-Gain) untuk tiap indikatornya. Dari tabel berikut dapat dilihat rata-rata peningkatan untuk masing-masing indikator kemampuan pemecahan masalah matematis siswa, diperoleh peningkatan pada indikator pertama "membuat model matematis" paling tinggi bila dibandingkan dengan peningkatan pada aspek yang lainnya yakni sebesar 0,635 dengan kriteria sedang. 
Tabel 2. Rata-rata Peningkatan Kemampuan Pemecahan Masalah Matematik Kelas Eksperimen

\begin{tabular}{|c|c|c|c|}
\hline \multicolumn{2}{|c|}{ Aspek } & $\begin{array}{l}\text { Indikator Kemampuan Pemecahan } \\
\text { Masalah }\end{array}$ & $\begin{array}{c}\text { Rata-rata } \\
\text { N-Gain }\end{array}$ \\
\hline \multicolumn{2}{|c|}{ Membuat Model Matematis } & $\begin{array}{l}\text { Mengubah informasi pada masalah } \\
\text { kedalam model matematika hingga dapat } \\
\text { membedakan sistem persamaan linear } \\
\text { dan yang bukan sistem persamaan linear }\end{array}$ & $\begin{array}{c}0.635 \\
\text { (Sedang) }\end{array}$ \\
\hline \multicolumn{2}{|c|}{$\begin{array}{l}\text { Memilih strategi pemecahan } \\
\text { masalah yang tepat }\end{array}$} & $\begin{array}{l}\text { Mengaitkan informasi yang diberikan } \\
\text { dengan strategi yang sesuai yakni } \\
\text { menggunakan eliminasi, substitusi atau } \\
\text { eliminasi gauss dan gauss Jordan. }\end{array}$ & $\begin{array}{c}0.358 \\
\text { (Sedang) }\end{array}$ \\
\hline \multirow{2}{*}{$\begin{array}{l}\text { Menjelaskan } \\
\text { jawaban dan } \\
\text { memeriksa } \\
\text { kebenarannya }\end{array}$} & $\begin{array}{l}\text { Menjelaskan } \\
\text { Jawaban }\end{array}$ & $\begin{array}{l}\text { Melakukan penafsiran dari informasi yang } \\
\text { diberikan / menjelaskan jawaban yang } \\
\text { diperoleh yakni SPL yang mempunyai atau } \\
\text { tanpa solusi dan memiliki solusi tungal } \\
\text { atau tak hingga solusi. }\end{array}$ & $\begin{array}{c}0.406 \\
\text { (Sedang) }\end{array}$ \\
\hline & $\begin{array}{l}\text { Memeriksa } \\
\text { Kebenaranny } \\
\text { a }\end{array}$ & $\begin{array}{l}\text { Melakukan pemeriksaan yang tepat yakni } \\
\text { memasukkan nilai yang diperoleh } \\
\text { sehingga data yang diketahui menjadi } \\
\text { benar }\end{array}$ & $\begin{array}{c}0.316 \\
\text { (Sedang) }\end{array}$ \\
\hline
\end{tabular}

Dari hasil pengujian Normalitas dan homogenitas data $\mathrm{N}$-gain kelas eksperimen dan kelas kontrol diperoleh bahwa data berdistribusi Normal dan Homogen.Berikut ini diperlihatkan hasil uji normalitas data Ngain kelas eksperimen dan kontrol dengan menggunakan SPSS 16:

Tabel 3 Hasil Uji Normalitas N-Gain Kelas Eksperimen dan Kelas Kontrol (Tests of Normality)

Tests of Normality

\begin{tabular}{|c|c|c|c|c|c|c|}
\hline \multirow{2}{*}{} & \multicolumn{3}{|c|}{ Kolmogorov-Smirnov ${ }^{\mathrm{a}}$} & \multicolumn{3}{c|}{ Shapiro-Wilk } \\
\cline { 2 - 7 } & Statistic & $\mathrm{Df}$ & Sig. & Statistic & $\mathrm{df}$ & Sig. \\
\hline Eksperimen & .094 & 14 & $.200^{*}$ & .971 & 14 & .895 \\
Kontrol & .149 & 14 & $.200^{*}$ & .949 & 14 & .548 \\
\hline
\end{tabular}

a. Lilliefors Significance Correction

*. This is a lower bound of the true significance.

Dari hasil uji Kolmogorov-Smirnov test tersebut, diketahui bahwa nilai signifikansi kelas eksperimen sebesar 0.200 dan kelas kontrol 0.200 . Karena nilai signifikansi kelas eksperimen dan kelas control sama yakni $0,200>a: 0,05$ maka data N-gain kelas eksperimen dan kelas kontrol berdistribusi normal. Selanjutnya untuk uji homogenitas data $\mathrm{N}$-gain kelas eksperimen dan kontrolpada penelitian ini menggunakan uji Bartlett, berikut ini tabel hasil uji homogenitas menggunakan SPSS 16: 
Hal : $23-28$

Tabel 4. Hasil Uji Homogenitas N-Gain Kelas Eksperimen dan Kelas Kontrol dengan Uji Bartlett

KMO and Bartlett's Test

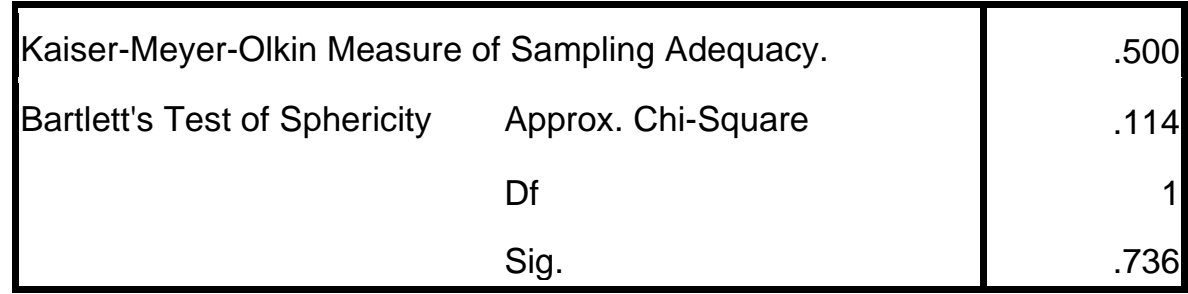

Dari hasil uji Bartlett menggunakan program SPSS tersebut, diketahui bahwa nilai signifikansi $0.736>$ $\alpha$ : 0,05 artinya data $\mathrm{N}$-gain kelas kontrol dan kelas eksperimen adalah homogen. Berdasarkan pengujian normalitas dan homogenitas di atas disimpulkan bahwa data $\mathrm{N}$-gain kemampuan pemecahan masalah berdistribusi normal dan homogen.

Untuk mengetahui perbedaan peningkatan kemampuan pemecahan masalah antara kelas eksperimen dan kelas kontrol digunakan uji statistik parametrik (karena data yang diperoleh normal dan homogen). Berdasarkan hasil perhitungan uji t diperoleh thitung $=23,22$, dan tabel $=2,144$, sehingga nilai thitung $>$ tabel artinya tolak $\mathrm{H}_{0}$ dan terima $\mathrm{H}_{\mathrm{a}}$.Jika menggunakan SPSS 16 dapat dilihat pada tabel berikut:

Tabel 5. Hasil Uji t data N-Gain Kemampuan Pemecahan Masalah

\begin{tabular}{|c|c|c|c|c|c|c|c|c|c|}
\hline \multicolumn{10}{|c|}{ Independent Samples Test } \\
\hline & \multicolumn{2}{|c|}{$\begin{array}{l}\text { Levene's } \\
\text { Test for } \\
\text { Equality of } \\
\text { Variances }\end{array}$} & \multicolumn{7}{|c|}{ t-test for Equality of Means } \\
\hline & \multirow[b]{2}{*}{$\mathrm{F}$} & \multirow[b]{2}{*}{ Sig. } & \multirow[b]{2}{*}{$\mathrm{t}$} & \multirow[b]{2}{*}{ Df } & \multirow{2}{*}{$\begin{array}{l}\text { Sig. (2- } \\
\text { tailed) }\end{array}$} & \multirow{2}{*}{$\begin{array}{c}\text { Mean } \\
\text { Difference }\end{array}$} & \multirow{2}{*}{$\begin{array}{l}\text { Std. Error } \\
\text { Difference }\end{array}$} & \multicolumn{2}{|c|}{$\begin{array}{c}95 \% \text { Confidence } \\
\text { Interval of the } \\
\text { Difference }\end{array}$} \\
\hline & & & & & & & & Lower & Upper \\
\hline $\begin{array}{l}\text { lai Equal } \\
\text { variances } \\
\text { assumed }\end{array}$ & .194 & .663 & 4.272 & 29 & .000 & .17845 & .04177 & .09301 & .26388 \\
\hline $\begin{array}{l}\text { Equal } \\
\text { variances } \\
\text { not } \\
\text { assumed }\end{array}$ & & & 4.322 & $\begin{array}{r}28.80 \\
2\end{array}$ & .000 & .17845 & .04129 & .09398 & .26291 \\
\hline
\end{tabular}

Berdasarkan output di atas diperoleh probabilitas (signifikansi) sebesar $0,000(<0,05)$, maka $\mathrm{H}_{0}$ ditolak, hal ini menandakan bahwa hipotesis nol yang menyatakan tidak terdapat perbedaan yang signifikan antara peningkatan kemampuan pemecahan masalah matematik siswa melalui pembelajaran berbasis masalah dengan pembelajaran secara konvensional ditolak yang berarti bahwa terdapat perbedaan rata-rata antara kedua kelas sampel. 
Hal : $23-28$

Berikut ini diperlihatkan tabel hasil pengujian hipotesis penelitian kemampuan pemecahan masalah matematik siswa.

\section{Tabel 6. Rangkuman Hasil Pengujian Hipotesis Penelitian Kemampuan Pemecahan Masalah Matematik Siswa}

\begin{tabular}{|l|l|l|}
\hline Hipotesis Penelitian & Pengujian $\mathbf{H}_{0}$ & Hasil Pengujian \\
\hline $\begin{array}{l}\text { Terdapat perbedaan yang } \\
\text { signifikan antara peningkatan } \\
\text { kemampuan pemecahan masalah } \\
\text { matematik siswa yang memperoleh } \\
\text { pembelajaran berbasis masalah } \\
\text { dengan siswa yang memperoleh } \\
\text { pembelajaran konvensional }\end{array}$ & & $\begin{array}{l}\text { Terdapat perbedaan yang } \\
\text { signifikan antara peningkatan } \\
\text { kemampuan pemecahan } \\
\text { masalah matematik siswa } \\
\text { yang memperoleh } \\
\text { pembelajaran berbasis } \\
\text { masalah dengan siswa yang } \\
\text { memperoleh pembelajaran } \\
\text { konvensional }\end{array}$ \\
\hline
\end{tabular}

\section{Kesimpulan}

Berdasarkan hasil penelitian tentang pelaksanaan pembelajaran berbasis masalah, diperoleh beberapa kesimpulan yang merupakan jawaban atas petanyaan-pertanyaan yang diajukan, diataranya:

1. Peningkatan kemampuan pemecahan masalah matematik siswa yang memperoleh pembelajaran berbasis masalah lebih tinggi daripada siswa yang memperoleh pembelajaran konvensional.

2. Terdapat perbedaan yang signifikan antara peningkatan kemampuan pemecahan masalah matematika siswa yang memperoleh pembelajaran berbasis masalah dengan siswa yang memperoleh pembelajaran konvensional.

3. Diantara keempat aspek pemecahan masalah, rata-rata peningkatan yang paling tinggi pada aspek "membuat model matematis" sebesar 0,635 dengan kriteria sedang.

\section{Daftar Pustaka}

[1] Ansari , B. I. (2009). Komunikasi Matematika Konsep dan Aplikasi.Banda Aceh: Yayasan PeNA.

[2] Arends, I.R. (2008). Belajar untuk Mengajar.Terjemahan oleh Helly.P dan Sri Mulyantini.Yogyakarta: Pustaka Pelajar.

[3] Napitupulu, E. E. (2011). Pengaruh Pembelajaran Berbasis Masalah atas KemampuanPenalaran dan Pemecahan Masalah Matematis serta Sikap terhadap Matematika Siswa Sekolah Menengah Atas. Bandung : Sekolah Pascasarjana, UPI.

[4] Polya, G. (1973). How to solve it: A new aspect of mathematics method. New Jersey: Princeton University Press.

[5] Ruseffendi,E.T. (1998). Statistika Dasar untuk Penelitian Pendidikan. Bandung. 